\title{
High-Quality Concretes for Foundations of the Multifunctional High-Rise Complex (MHC) «Akhmat Tower»
}

\author{
S.-A. Murtazaev ${ }^{1,2,3}$, M. Saydumov ${ }^{1(\bowtie)}$, A. Alaskhanov ${ }^{1}$, \\ and M. Nakhaev ${ }^{4}$ \\ ${ }^{1}$ Millionshchikov Grozny State Oil Technical University, Grozny, Russia \\ saidumov_m@mail.ru \\ 2 Ibragimov Complex Research Institute, RAS, Grozny, Russia \\ 3 Academy of Sciences of the Chechen Republic, Grozny, Russia \\ ${ }^{4}$ Chechen State University, Grozny, Russia
}

\begin{abstract}
The paper presents results of studies of monolithic concrete mixes and concretes produced with the integrated use of local natural and technogenic raw materials, including waste scrap and crushed bricks. We developed optimal compositions of monolithic concretes and studied their technological and physical-mechanical properties.
\end{abstract}

Keywords: High-strength concrete $\cdot$ High-quality concrete mix $\cdot$ Filled binder - Technogenic wastes $\cdot$ Mineral technogenic filler Monolithic concrete

\section{Introduction}

The modern materials science and construction now deal with an important national economic and engineering problem: development of efficient technologies for producing high-strength monolithic concretes through the integrated use of technogenic raw materials to obtain secondary raw materials for concrete, while eliminating the enormous environmental damage caused by waste "cemeteries" (Bazhenov et al. 2006; Salamanova et al. 2017; Lesovik et al. 2012; Murtazaev et al. 2009; Kaprielov et al. 2018) in Russia and the world and, in particular, for the Chechen Republic, considering construction of 435-m high-rise complex «Akhmat-Tower» in Grozny City (Udodov 2015; Koryanova et al. 2018; Salamanova and Murtazaev 2018).

\section{Methods and Materials}

Our experimental studies used local additive-free Portland cement of PC 500 D0 grade as a binder. Natural sand from the Chervlensky deposit of the Chechen Republic was used as a fine filler. Local gravel of 5-20 mm fractions from the Argunsky and Sernovodsky deposits of the Chechen Republic and imported crushed stone of 5-20 mm 
fraction from granite-diabase rocks of the Alagirsky deposit of the Republic of North Ossetia-Alania were used as a coarse filler.

As plastifying agents in accordance with GOST 24211-2008 "Additives for concrete. General technical requirements" modern additives of various manufacturers of building chemicals (POLYPLAST, TOKAR, etc.) were used.

The raw materials for the production of dispersed technogenic mineral fillers (DTMF) were local materials, mainly technogenic, namely concrete scrap, crushed ceramic bricks (CCB), ash and slag mixture from the Grozny heat and power plant (HPP) and very small non-conditioned quartz sands ones were used in comparative tests.

All the DTMFs were ground for $5 \mathrm{~min}$ in MV-20-EX laboratory vibratory ball mill with a loading volume of 5-6 L to obtain a specific surface of $450-600 \mathrm{~m}^{2} / \mathrm{kg}$.

\section{Results and Discussion}

The Filled Binder (FB) formulation was developed and investigated with activity 60 $71 \mathrm{MPa}$ with concrete scrap and CCB fillers with ratio 70:30\%. The proportion of the mixture of filler in FB was 25 and $40 \%$ by weight of the binder.

Due to the fact that for designing the underground part of the Akhmat Tower multifunctional complex, concrete of different strength classes (B40, B75-B80) was laid, the task was to develop high-quality concrete mixes (HCM), starting from the middle B40-B50 classes and ending with high-strength concrete of B80-B90 classes, with the integrated use of local raw materials, including with technogenic nature.

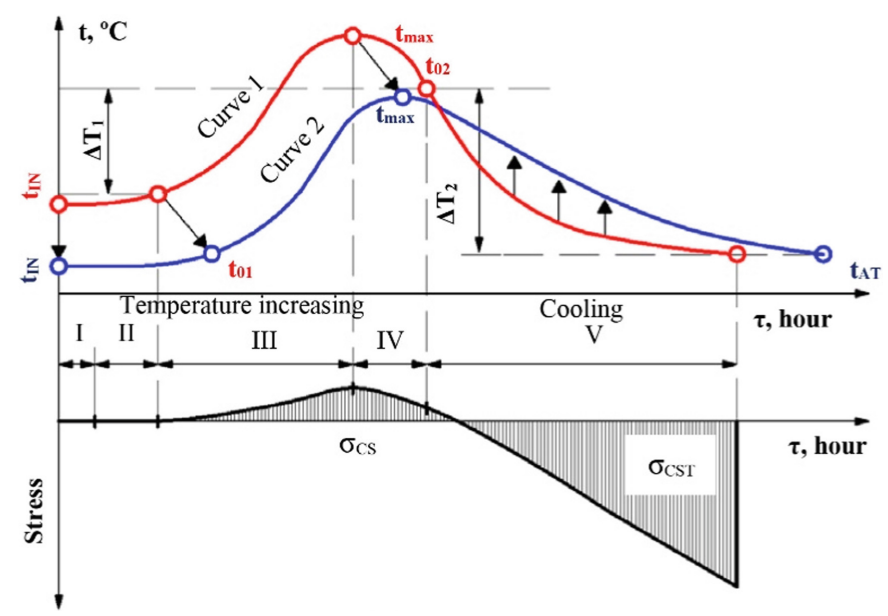

Fig. 1. Temperature change and stress characteristic in fresh concrete with limited deformation: $\sigma_{\mathrm{CS}}$ - internal compressive stresses; $\sigma_{\mathrm{CST}}$ - the same, tensile; $\mathrm{t}_{\mathrm{IN}}$ - initial temperature of concrete mixture; tmax - the same, maximum; $\mathrm{t}_{\mathrm{AT}}$ - ambient temperature (air); I, II, ... V - stages (periods) of process of heat dissipation of the concrete mix in time; curve 1 - kinetics of heat dissipation of concrete with PC; curve 2 - the same with FB 
In massive building constructions, such as the Akhmat Tower MFC base plate, because of their large dimensions, as a rule, the heat from cement hydration is slowly released into the air or into adjacent structural elements, as a result of which the core of the monolithic element heats up much faster and stronger than the shell. Therefore, we investigated thermophysical processes of the developed compositions.

Figure 1 schematically shows the dependence of temperature and voltage due to external pressure generated by this concreting technology.

The dependence of heat release curves in time is conventionally divided into 5 stages (Table 1).

Table 1. The main stages (periods) of the process of heat dissipation in time of concrete mixes with various binders

\begin{tabular}{|c|c|c|c|}
\hline \multirow{2}{*}{$\begin{array}{l}\text { Stage } \\
\text { № }\end{array}$} & \multicolumn{2}{|c|}{ Duration, $h$} & \multirow[t]{2}{*}{ Description } \\
\hline & $\begin{array}{l}\text { With } \\
P C\end{array}$ & $\begin{array}{l}\text { With } \\
F B\end{array}$ & \\
\hline 1 & $0-2$ & $0-8$ & $\begin{array}{l}\text { The initial stage without raising the temperature of the concrete mix } \\
\text { (dormant period). This period is significantly increased due to the use } \\
\text { of surface-active substances (surfactants) in the composition of FB, } \\
\text { hardening retarders, etc. }\end{array}$ \\
\hline 2 & $2-6$ & $8-15$ & $\begin{array}{l}\text { Temperature increase due to hydration of the binder, no measurable } \\
\text { stress, because in the plastic concrete, thermal expansions are } \\
\text { converted to relative compression. At the end of this stage, the } \\
\text { temperature is referred to as "the first temperature at zero stress" } t_{01}\end{array}$ \\
\hline 3 & $6-13$ & $15-24$ & $\begin{array}{l}\text { Further heating of the concrete, the strength of the concrete increases } \\
\text { and a compressive stress is formed, partially decreasing because of } \\
\text { relaxation. Stage III ends when the maximum temperature tmax is } \\
\text { reached }\end{array}$ \\
\hline 4 & $\begin{array}{l}13- \\
24\end{array}$ & $24-72$ & $\begin{array}{l}\text { Heat transfer prevails: the temperature of concrete and compressive } \\
\text { stress in concrete decrease, a part of compressive stress decreases } \\
\text { because of relaxation. The "second temperature at zero stress" } t_{02} \text { is } \\
\text { reached, which significantly exceeds } t_{01} \text { in cooling rate and age of } \\
\text { concrete }\end{array}$ \\
\hline 5 & $\begin{array}{l}24- \\
72\end{array}$ & $72-144$ & $\begin{array}{l}\text { Further cooling and increasing tensile stress, which are partially } \\
\text { reduced due to relaxation. If the tensile stress reaches the tensile } \\
\text { strength of the concrete under tension (at } \Delta \mathrm{T}_{\text {КРит) through cracks are }} \\
\text { formed }\end{array}$ \\
\hline
\end{tabular}

According to calculations (Kaprielov et al. 2018), the temperature difference between the upper surface layers of concrete slab and outside air $\Delta \mathrm{T} 1$ should be no more than $20{ }^{\circ} \mathrm{C}$, and the difference between the side layers $\Delta \mathrm{T} 2$ - no more than $30{ }^{\circ} \mathrm{C}$. 


\section{Conclusions}

Thus, analysis of data confirms the effectiveness of the use of FB with DTMF in highquality concretes used for concreting massive structures. We established that the peak of the maximum heat release tmax from the exotherm of cement in (massive) concrete on $\mathrm{HB}$ was reduced by $30-35 \%$ in comparison to the concrete with $\mathrm{PC}$ (from $70-75^{\circ} \mathrm{C}$ to $50-55^{\circ} \mathrm{C}$ ).

\section{References}

Bazhenov YM, Demyanova BC, Kalashnikov VI (2006) Modified high-quality concretes. Publishing House of the Association of Construction Universities, Moscow, $368 \mathrm{p}$

Kaprielov SS, Sheinfeld AV, Al-Omais D (2018) Experience in the production and quality control of high-strength concrete on the construction of the high-altitude complex "OKO" in Moscow-City International Business Center. Industrial and Civil Construction, no 1, pp 1824

Koryanova YI, Rezantsev NE, Shumilova AS (2018) Materials and structures used in the construction of high-rise buildings - from tradition to innovation. Alley Sci 6(4):95-99

Lesovik BC, Murtazaev SAY, Saydumov MS (2012) Construction composites based on screenings of crushing of concrete scrap and rocks. MUP "Typography", Groznyy, $192 \mathrm{p}$

Murtazaev S-AY, Bataev DK-S, Ismailova ZK (2009) Fine-grained concretes based on fillers from secondary raw materials. Comtechprint, Moscow, $142 \mathrm{p}$

Salamanova M, Khubaev M, Saidumov M, Murtazayeva T (2017) Int J Environ Sci Educ 11 (18):12719-12724

Salamanova MS, Murtazaev SAY (2018) Clinker-free binders based on finely dispersed mineral components. In: Collection: Ibausil Conference Proceedings, pp 707-714

Udodov SA (2015) Re-introduction of plasticizer as a tool for controlling the mobility of concrete mix. In: Proceedings of the Kuban State Technological University, no 9, pp 175-185

Open Access This chapter is licensed under the terms of the Creative Commons Attribution 4.0 International License (http://creativecommons.org/licenses/by/4.0/), which permits use, sharing, adaptation, distribution and reproduction in any medium or format, as long as you give appropriate credit to the original author(s) and the source, provide a link to the Creative Commons license and indicate if changes were made.

The images or other third party material in this chapter are included in the chapter's Creative Commons license, unless indicated otherwise in a credit line to the material. If material is not included in the chapter's Creative Commons license and your intended use is not permitted by statutory regulation or exceeds the permitted use, you will need to obtain permission directly from the copyright holder.

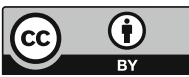

